\title{
Accumulation and Distribution of Minerals and Heavy Metals in Sugar Beet and Carrot Plants Grown on Soil Amended with Filter Mud Cake
}

\author{
Fawzy M. Salama ${ }^{(1) \#, \text { Noha A. El-Tayeh }{ }^{(2)} \text {, Naglaa Loutfy }}{ }^{(2)}$, Mona F. Abou \\ Alhamd $^{(2)}$ \\ (1) Botany Department, Faculty of Science (Assuit) , Assuit University, Egypt; ${ }^{(2)}$ Botany \\ and Microbiology Department, Faculty of Science (Qena), South Valley University, \\ Egypt.
}

\begin{abstract}
TILTER mud cake (FMC) collected from Qus sugarcane factory at Qena in Egypt was applied in a pot experiment to investigate the uptake and distribution of certain mineral nutrients and some heavy metals in different organs of both experimental plants. The filter mud cake was mixed with sand at three levels: $10 \%, 30 \%$ and $50 \%$ and the sand was used (without FMC) as control. Results showed that amendment the sandy soil with filter mud cake resulted in increasing in $\mathrm{K}$ and, Ca contents in both experimental plants. Moreover, $\mathrm{Mg}$ content had irregular behavior by decrease or increase. Na content- in contrast to $\mathrm{Ca}$ and $\mathrm{K}$ showed significant decrease of carrot and sugar beet plants. The distribution of $\mathrm{Na}$ and $\mathrm{K}$ was in another way, and mostly $\mathrm{Na}$ accumulated in roots while more $\mathrm{K}$ transported into shoots of both plants. Results indicated also that $\mathrm{Na} / \mathrm{K}$ ratio was higher in plant roots than in shoots. Data revealed that FMC stimulated the accumulation of $\mathrm{Cl}, \mathrm{PO}_{4}$ and $\mathrm{SO}_{4}$ content in two tested plants as compared with control. $\mathrm{Mg}, \mathrm{Ca}, \mathrm{Cl}, \mathrm{SO}_{4}$ and $\mathrm{PO}_{4}$ distributed in shoots and roots with significant change from the roots toward the shoots. Generally, FMC treatments increased $\mathrm{Zn}$, $\mathrm{Cu}, \mathrm{Pb}$ and $\mathrm{Cd}$ accumulation in carrot and sugar beet plants compared to control. Correlation analysis between the contents of heavy metals in both organs of carrot and sugar beet plants and that in the sand-FMC mixture showed different relationships.
\end{abstract}

Keywords: Sugar beet, Carrot, Filter mud cake, Heavy metals, Minerals.

\section{Introduction}

Soils of the new cultivated desert in Egypt are low in their organic matter content. Organic amendments should be added to these soils to improve their chemical, physical and biological properties as well as fertility. According to Abo-baker (2017) it is important to apply organic matter to the new cultivated soils because soil cultivation enhances the rate of soil degradation and decomposition of soil organic matter. Filter mud cake (FMC) or Press mud (PM), a residue from the treatment of sugar cane juice by filtration, is a rich source of phosphorus and organic matter and has large moisture content. Prado et al. (2013) reported that using FMC as a complete or partial substance for mineral fertilizers in sugar cane cultivation, in the planting of other crops, in vermicomposting, in composting and as a substrate in the production of seedlings. Razzaq (2001) reported that, continuous land application of sugarcane FMC to agricultural crops for 5-6 years due to improve soil fertility by adding sulfur (S) and organic matter to soil. FMC is rich in sugar and contains appreciable amount of essential plant nutrients viz., macronutrients ( $\mathrm{P}, \mathrm{K}, \mathrm{Ca}$ and $\mathrm{Mg}$ ), organic carbon, nitrogen and traces of micronutrients viz., ( $\mathrm{Zn}, \mathrm{Fe}, \mathrm{Cu}$ and $\mathrm{Mn}$ ), so it use for enhancing the soil fertility and thereby improving the crop productivity (Kumar \& Chopra, 2016). FMC improves soil nutrient availability and uptake by plants (Muhammad \& Khatta, 2009). Rizk (2012) reported that cover crop with mineral fertilizer treatment increased mineral content in leaf petioles. Application of FMC to the soil increased the total N, P and $\mathrm{K}$ according to Hadad et al. (2015). Hassan (1999) indicated that wheat plants grown on sandy and sandy calcareous soils treated with composted sugar beet residues contain a significant increase in $\mathrm{K}, \mathrm{P}$ and N. In addition, Taha (2000) reported that the application of different composted organic residues significantly increased the uptake of

\#Corresponding author email: fawzysalama2020@yahoo.com

DOI: 10.21608 /ejbo.2018.4856.1200

Edited by: Prof. Dr. Wedad Kasim, Faculty of Science, Tanta University, Tanta, Egypt.

(C)2019 National Information and Documentation Center (NIDOC) 
$\mathrm{N}, \mathrm{P}$ and $\mathrm{K}$ by corn plants over the control and the increase was proportional to the increase in the composted organic residues level. PM application induced increase in S and Ca uptake. As well, Long-term application of sulphitation PM increases the content of $\mathrm{Cu}, \mathrm{Fe}$ and $\mathrm{Zn}$ in sugar beet (Solaimala et al., 2001). Chauhan (1995) found that $\mathrm{Zn}$ contents of rice plants increased when $50 \%$ of required gypsum was applied with $15 \mathrm{mg} \mathrm{ha}^{-1}$ filter mud cake. Kumar \& Chopra (2016) observed that Solanum melongena plants had the highest contents of $\mathrm{Cd}, \mathrm{Cr}, \mathrm{Cu}, \mathrm{Mn}$ and $\mathrm{Zn}$ with $100 \%$ treatment of the sugarcane PM.

Carrot and sugar beet in Egypt are among most popular root vegetables. Carrots are a serious source of sugars and minerals like $\mathrm{Ca}, \mathrm{P}, \mathrm{Fe}$ and $\mathrm{Mg}$ (Sharma et al., 2012). This root vegetable contains valuable phytochemicals. Red sugar beet has been cultivated already in ancient Egypt. The taproot contains vitamins A, B1, B2, B3, B4, B5, B6, B12, $\mathrm{C}$, anthocyanins and $\mathrm{Fe}, \mathrm{Ca}, \mathrm{Mg}, \mathrm{K}, \mathrm{Mn}, \mathrm{Cu} \mathrm{Cl}$, F, Zn, B, Li, Mo, Co, Rb and Cs (www.trafoon. org/sites/trafoon.org/files/download/1196/olsztyn_ lech_michalczuk_20160912.pdf).

Therefore the present study was carried out to evaluate filter mud cake as organic fertilizer treatments and its effect on the uptake and distribution of mineral element and heavy metals in carrot and sugar beet plants.

\section{Materials and methods}

\section{Plant materials and growth conditions}

Filter mud cake (FMC) was obtained from Qus sugarcane factory, Qena Governorate, Egypt. Different levels of FMC-sand mixture (thoroughly mixed) were used for this study. The filter mud cake was mixed with sand at three levels: $10 \%$, $30 \%$ and $50 \%$ (w:w filter mud cake:sand). The sand was used (without FMC) as a control. The pot experiments were arranged in a complete random design using plastic pots of $35 \mathrm{~cm}$ in diameter and $40 \mathrm{~cm}$ in height and; each one was filled with $6 \mathrm{~kg}$ of the investigated sand soil and 3 pots for each level were prepared (totally 12 pots). Experiments were conducted in the screen house and experimental farm, Faculty of Science, South Valley University, Egypt and the field capacity was determined for each FMC level before cultivating the seeds.

Carrot (Daucus carota) and sugar beet plants (Beta vulgaris) were used as plant materials. Seeds were provided by the Agronomy Department, Faculty of Agriculture, Assiut University. Five analogous individuals were left in each pot and irrigated regularly with distilled water to field capacity level. The amount of water lost per day was compensated for each field capacity of FMC levels. Plants were allowed to grow 10 weeks before the experiment was terminated. During germination and growth, all plants were received Hoagland's solution (Hoagland \& Arnon, 1950). Hoagland's solution was added partially at five days intervals at the level of field capacity.

At the end of the experiment, shoots and roots of the plants were weighed and oven-dried and then powdered for extraction and chemical analysis. Shoots and roots extracts were prepared for minerals analysis $\left(\mathrm{Cl}, \mathrm{SO}_{4}, \mathrm{PO}_{4}, \mathrm{Na}, \mathrm{K}, \mathrm{Ca}\right.$ and $\mathrm{Mg}$ according to Richards (1954). For heavy metals analysis, the mixed acid digestion procedure as described by Allen (1989) was used for preparing the extracts of different FMC levels or the plant materials. The Total contents of $\mathrm{Cu}, \mathrm{Zn}, \mathrm{Cd}$ and $\mathrm{Pb}$ were estimated using an atomic absorption spectrophotometer. Chlorides were determined by silver nitrate $\left(\mathrm{AgNO}_{3}\right)$ titration method as described by Johnson \& Ultrich (1959). Sulphates were determined by a turbid-metric technique as $\left(\mathrm{BaSO}_{4}\right)$ according to Bardsley \& Lancaster (1965). Phosphates were estimated by the method described by Vogler (1965). Sodium and potassium were determined by the flame emission technique (Williams \& Twine, 1960). Calcium and magnesium were determined volumetrically by versene titration method as described by Schwarzenbach \& Biedermann (1948).

Data were statistically analyzed using SPSS version 21 software. Analysis of variance (ANOVA) was carried using a general one-way model, and Duncan's test was used for comparison between means. The correlation analysis (r-value) was carried out between the studied heavy metals in soil and plants.

\section{$\underline{\text { Results }}$}

The content and distribution of minerals in plants

\section{Cations}

The data presented in Figs. 1 and 2 showed that there was a significant increase in $\mathrm{K}$ and $\mathrm{Ca}$ contents in carrot and sugar beet plants under FMC treatments compared to control. For example, $\mathrm{K}$ activity reached a maximum value (about 
2.5 fold higher than control ) at 30\% FMC in both shoots and roots of two tested plants and remained significantly higher than control at 10 and 50\% FMC (Figs. 1 and 2). On the other hand, the data presented showed that the highest content of $\mathrm{Ca}$ in shoots of carrot $(64.7 \%$ higher than control) and in shoots of sugar beet $(160 \%$ higher than control) in observed at 50\% FMC. There is a random increase in Ca content in roots of two tested plants. This increase was about 1.5 fold in sugar beet at $10 \%$ of FMC. Furthermore, $\mathrm{Mg}$ content had irregular effects by decrease or increase. $\mathrm{Na}$ content in contrast to the other minerals showed significant decrease in shoots of carrot and sugar beet reach $50 \%$ of control at the higher level of FMC (50\%), but in roots, there was random increase in comparison with the control plant (Figs. 1 and 2). The accumulation of $\mathrm{Ca}$ in control roots of carrot and sugar beet $(0.21 \mathrm{mg} / \mathrm{g}$ DW and $0.08 \mathrm{mg} / \mathrm{g} \mathrm{DW}$, respectively) was higher than control shoots $(0.17 \mathrm{mg} / \mathrm{g}$ DW and $0.05 \mathrm{~m} / \mathrm{g}$ DW and $3.2 \mathrm{mg} / \mathrm{g}$ DW). Also accumulation of $\mathrm{Na}$ control roots of carrot and sugar beet $(3.91 \mathrm{mg} / \mathrm{g}$ DW and $4.31 \mathrm{mg} / \mathrm{g}$ DW, respectively) was higher than control shoots $(2.8 \mathrm{mg} / \mathrm{g}$ DW and $3.2 \mathrm{mg} / \mathrm{g}$ $\mathrm{DW})$. Moreover accumulation of $\mathrm{Mg}$ in control roots of sugar beet was increased by $77.77 \%$ than control shoots of sugar beet. Conversely, the $\mathrm{K}$ accumulation was increased in control shoots of carrot and sugar beet $(141.66 \%$ and $100 \%$, respectively) than control roots of carrot and sugar beet.

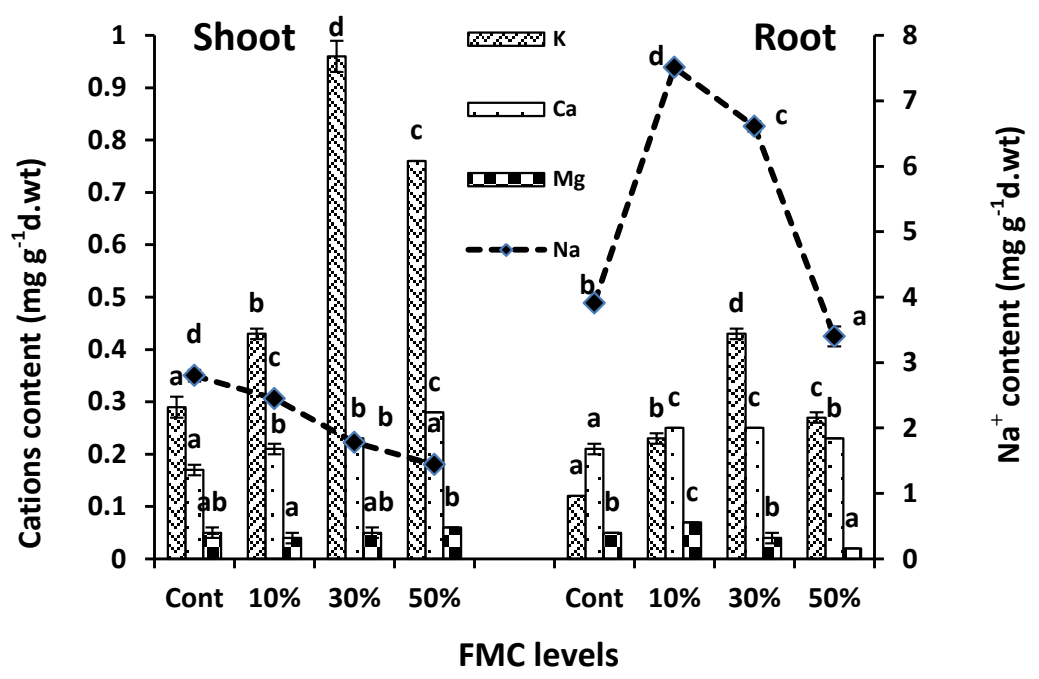

Fig. 1. Concentration of major cations ( $\mathrm{Na}, \mathrm{K}, \mathrm{Ca}$ and $\mathrm{Mg}$; in $\mathrm{mg} \mathrm{g}^{-1} \mathrm{dry} \mathrm{wt}$ ) in shoots and roots of carrot plants grown on sand "control" and different levels of FMC [Data are means \pm SE, $n=3$, data of each ion in each panel with different letters are significantly different at $P>0.05$ according to Duncan Test].

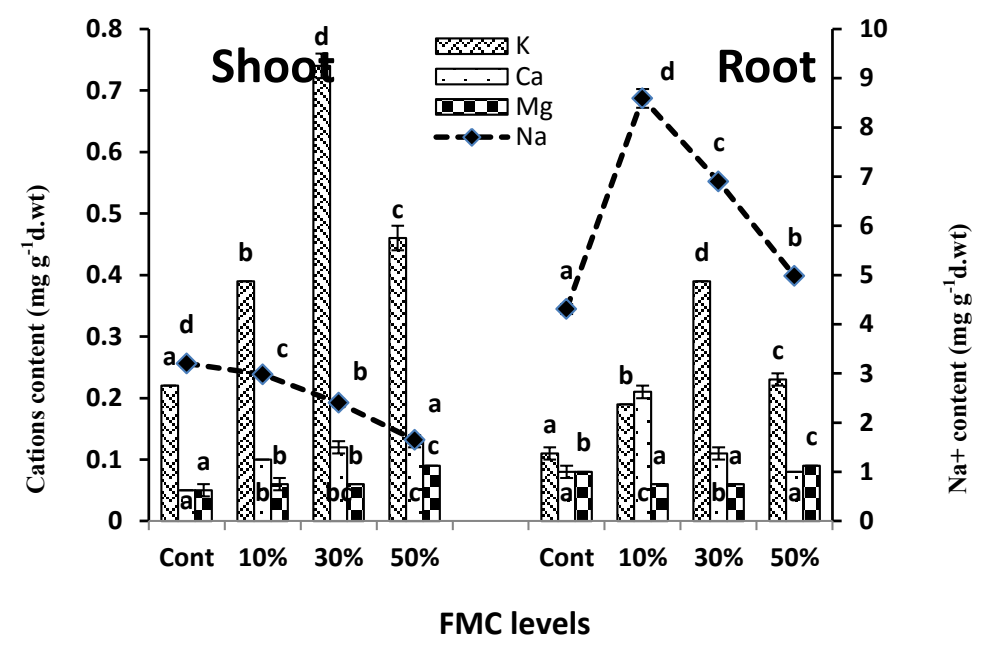

Fig. 2. Concentration of major cations ( $\mathrm{Na}, \mathrm{K}, \mathrm{Ca}$ and $\mathrm{Mg}$; in $\mathrm{mg} \mathrm{g}^{-1} \mathrm{dry} \mathrm{wt}$ ) in shoots and roots of sugar beet plants grown on sand "control" and different levels of FMC [Data are means $\pm S E, n=3$, data of each ion in each panel with different letters are significantly different at $P>0.05$ according to Duncan Test]. 
The FMC significantly decreased $\mathrm{Na} / \mathrm{K}$ ratio in carrot and sugar beet plants which was maximum (about $80 \%$ and lesser than control) in shoots, (62\% lesser than control) in roots of carrot at $50 \%$ FMC and (55\% lesser of control) in roots of sugar beet at $30 \%$ (Tables 1 and 2).

\section{Anions}

FMC stimulated the accumulation of $\mathrm{Cl}, \mathrm{PO}_{4}$ and $\mathrm{SO}_{4}$ content in two tested plants as compared with control (Figs. 3 and 4).

The data showed that the highest increase of $\mathrm{Cl}$ was in shoots $(76.92 \%$ and $50.05 \%$ of control) of carrot and sugar beet, respectively at $50 \%$ of FMC. But at the same level of FMC, the increase was $(34.61 \%$ and $25.03 \%$ of control) in roots of carrot and sugar beet respectively. There are increases in $\mathrm{Cl}$ content in control roots of carrot and sugar beet (100\% and $75.02 \%$, respectively) than control shoots of carrot and sugar beet.

$\mathrm{SO}_{4}$ content reach the highest increase
(144.96\% and $197.49 \%$ of control) in shoots of carrot and sugar beet, respectively at $30 \%$ of FMC. While in roots, the highest increase was $146.33 \%$ in carrot at $10 \%$ of FMC and $91.91 \%$ in sugar beet at $50 \%$ of FMC. The increase of $\mathrm{SO}_{4}$ in control roots of carrot and sugar beet was $172.13 \%$ and $61.16 \%$ higher than control shoots of carrots and sugar beet, respectively.

The highest increase is $(192.08 \%$ of control) in $\mathrm{PO}_{4}$ content in roots of carrot at $30 \%$ of FMC. But the highest increase (45\% of control) in $\mathrm{PO}_{4}$ content was in both shoots and roots of sugar beet at $10 \%$ of FMC. $\mathrm{PO}_{4}$ content in control roots of carrot and sugar beet was about 2 and 1 fold than $\mathrm{PO}_{4}$ content in control shoots of carrot and sugar beet, respectively.

The content and distribution of heavy metals in plants

The data presented in Figs. 5 and 6 showed that in general, FMC treatments increased $\mathrm{Zn}, \mathrm{Cu}$, $\mathrm{Cd}$ and $\mathrm{Pb}$ accumulation in carrot and sugar beet under compared to control.

TABLE 1. One way ANOVA and means $\pm \mathrm{SE}$ of $\mathrm{Na} / \mathrm{K}$ ratios in different organs of carrot plant grown on different levels of FMC.

\begin{tabular}{lcc}
\hline & \multicolumn{2}{c}{$\mathbf{N a}^{+} / \mathbf{K}^{+}$} \\
\hline Sreatment & Shoot & Root \\
\hline Sand (control) & $9.81^{\mathrm{c}} \pm 0.63$ & $33.62^{\mathrm{b}} \pm 1.44$ \\
$10 \%$ & $5.78^{\mathrm{b}} \pm 0.20$ & $32.25^{\mathrm{b}} \pm 1.15$ \\
$30 \%$ & $1.86^{\mathrm{a}} \pm 0.07$ & $15.58^{\mathrm{a}} \pm 0.43$ \\
$50 \%$ & $1.90^{\mathrm{a}} \pm 0.08$ & $12.46^{\mathrm{a}} \pm 0.61$ \\
F value & $125.92^{* *}$ & $121.14^{* *}$ \\
\hline
\end{tabular}

Values with different superscript letters are significantly different at $\mathrm{P}<0.05$ according to Duncan Test.

$*$ and ** are significant at $\mathrm{P}<0.05$ and $\mathrm{P}<0.01$, respectively.

TABLE 2. One way ANOVA and means $\pm \mathrm{SE}$ of $\mathrm{Na} / \mathrm{K}$ ratios in different organs of sugar beet plant grown on different levels of FMC.

\begin{tabular}{|c|c|c|c|}
\hline \multirow{2}{*}{\multicolumn{2}{|c|}{ Treatment }} & \multicolumn{2}{|c|}{$\mathbf{N a}^{+} / \mathbf{K}^{+}$} \\
\hline & & Shoot & Root \\
\hline Sand (control) & & $14.90^{c} \pm 0.39$ & $39.30^{c} \pm 1.73$ \\
\hline $10 \%$ & & $7.73^{b} \pm 0.06$ & $45.20^{\mathrm{d}} \pm 1.08$ \\
\hline $30 \%$ & & $3.25^{\mathrm{a}} \pm 0.13$ & $17.53^{\mathrm{a}} \pm 0.24$ \\
\hline $50 \%$ & & $3.60^{\mathrm{a}} \pm 0.19$ & $22.14^{\mathrm{b}} \pm 0.36$ \\
\hline F value & & $537.65^{* *}$ & $162.66^{* *}$ \\
\hline
\end{tabular}

Values with different superscript letters are significantly different at $\mathrm{P}<0.05$ according to Duncan Test.

$*$ and $* *$ are significant at $\mathrm{P}<0.05$ and $\mathrm{P}<0.01$, respectively. 


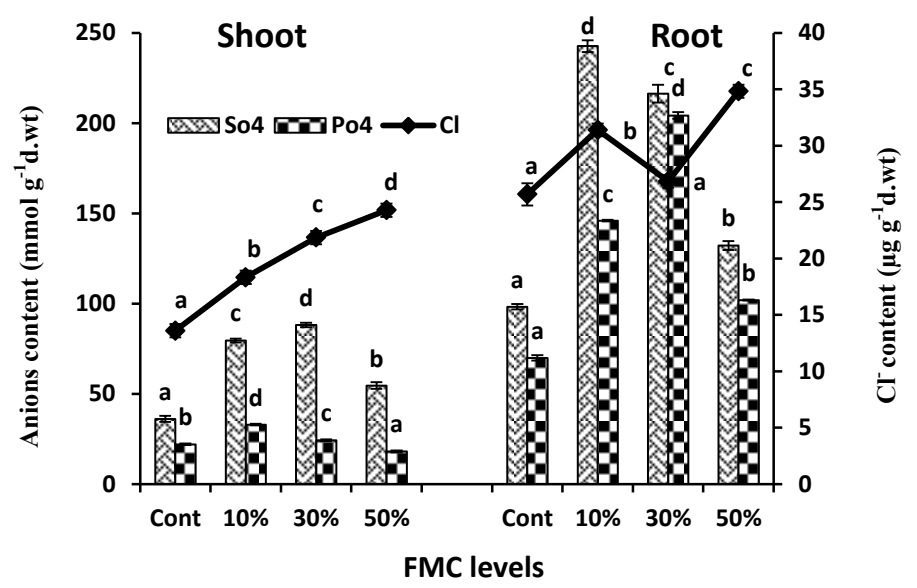

Fig. 3. Concentration of major anions (line for $\mathrm{Cl}$ in $\mu \mathrm{g} \mathrm{g} \mathrm{g}^{-1} \mathrm{dry}$ wt; $\mathrm{SO}_{4}$ and $\mathrm{PO}_{4}$ in mmol $\mathrm{g}^{-1} \mathrm{dry}$ wt) in shoots and roots of carrot plants grown on sand "control" and different levels of FMC [Data are means $\pm S E, n=3$, data of each ion in each panel with different letters are significantly different at $\mathbf{P}>0.05$ according to Duncan Test].

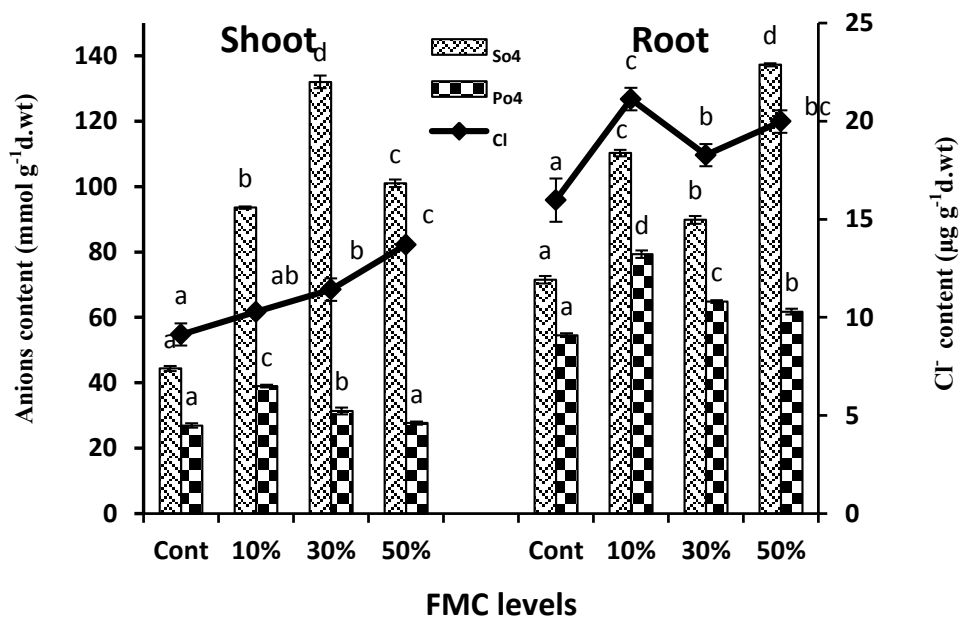

Fig. 4. Concentration of major anions (line for $\mathrm{Cl}$ in $\mu \mathrm{g} \mathrm{g}^{-1} \mathrm{dry} w \mathrm{wt} \mathrm{SO}_{4}$ and $\mathrm{PO}_{4}$ in mmol $\mathrm{g}^{-1} \mathrm{dry}$ wt) in shoots and roots of sugar beet plants grown on sand "control" and different levels of FMC [Data are means \pm SE, $n=3$, data of each ion in each panel with different letters are significantly different at $\mathbf{P}>0.05$ according to Duncan Test].

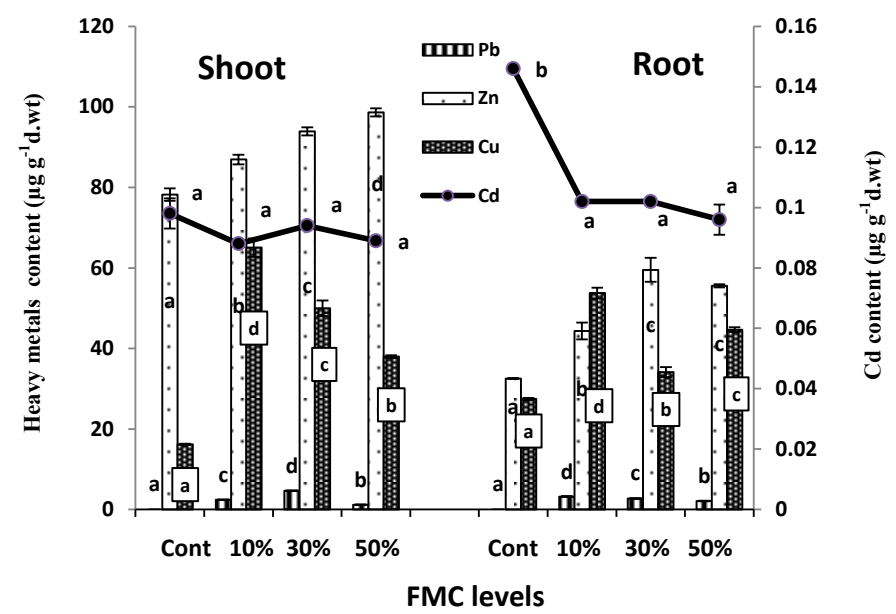

Fig. 5. Concentration of heavy metals (line for $\mathrm{Cd}$ in $\mu \mathrm{g} \mathrm{g}^{-1} \mathrm{dry}$ wt; $\mathrm{Zn}, \mathrm{Cu}$ and $\mathrm{Pb}$ in $\mu \mathrm{g} \mathrm{g}^{-1}$ dry wt) in shoots and roots of carrot plants grown on sand "control" and different levels of FMC [Data are means $\pm S E, n=3$, data of each ion in each panel with different letters are significantly different at $\mathbf{P}>0.05$ according to Duncan Test]. 


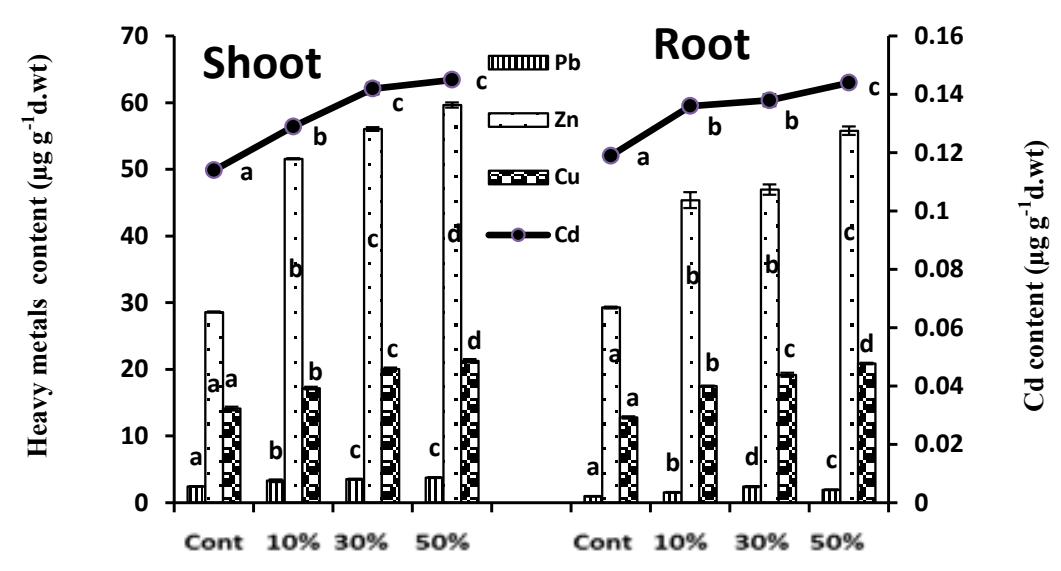

\section{FMC levels}

Fig. 6. Concentration of heavy metals (line for $\mathrm{Cd}$ in $\mu \mathrm{g} \mathrm{\textrm {g } ^ { - 1 }} \mathrm{dry} \mathrm{wt} ; \mathrm{Zn}, \mathrm{Cu}$ and $\mathrm{Pb}$ in $\mu \mathrm{g} \mathrm{\textrm {g } ^ { - 1 }}$ dry wt) in shoots and roots of sugar beet plants grown on sand "control" and different levels of FMC [Data are means \pm SE, n=3, data of each ion in each panel with different letters are significantly different at $P>0.05$ according to Duncan Test].

The maximum increase of $\mathrm{Zn}$ was in roots of carrot (83\% higher than control) at 30\% FMC. In sugar beet, the increase of $\mathrm{Zn}$ in shoots and roots was $108.78 \%$ and $90.60 \%$, respectively at $50 \%$ FMC as compared with control. The increase of $\mathrm{Zn}$ in carrot control shoots was $140.35 \%$ than carrot control roots. Conversely the $\mathrm{Zn}$ content in both controls shoots and roots of sugar beet was almost equal.

$\mathrm{Cu}$ had maximum increase in shoots of carrot (295.13\% higher than control at 10\%, FMC). While in roots of carrot, the increase was $95.79 \%$ higher than control at the same FMC level. Moreover, in shoots of sugar beet, the maximum increase was $50.81 \%$ at $50 \%$ FMC. And in sugar beet roots was $63.23 \%$ at the same FMC level. The content of $\mathrm{Cu}$ in carrot control roots $(27.46 \mu \mathrm{g} / \mathrm{g} \mathrm{DW})$ was higher than carrot control shoots $(16.14 \mu \mathrm{g} / \mathrm{g} \mathrm{DW})$. On the other hand in sugar beet, $\mathrm{Cu}$ content in control shoots $(14.11 \mu \mathrm{g} / \mathrm{g} \mathrm{DW})$ was higher than in control roots $(12.78 \mu \mathrm{g} / \mathrm{g} \mathrm{DW})$.

The maximum value in $\mathrm{Pb}$ was $4.64 \mu \mathrm{g} / \mathrm{g}$ DW at $30 \% \mathrm{FMC}$ in shoots of carrot, and was $3.22 \mu \mathrm{g} / \mathrm{g}$ DW in roots at $10 \%$ FMC. In sugar beet, while the maximum increase in $\mathrm{Pb}$ of shoots was $53.68 \%$ at $50 \%$ FMC as compared with control. The increase in roots was $146.39 \%$ at $30 \%$ FMC as compared with control. The value of $\mathrm{Pb}$ in both controls shoots and roots of carrots control was zero. Conversely the increase of $\mathrm{Pb}$ in sugar beet control shoots was $151.44 \%$ than sugar beet control roots.

$\mathrm{Cd}$ in contradiction of $\mathrm{Zn}, \mathrm{Cu}$ and $\mathrm{Pb}$ revealed significantly reduction when treated the carrot plants with FMC. Conversely, there is a highly significant increase in $\mathrm{Cd}$ content in sugar beet plants. The maximum decrease was $39.8 \%$ lesser than control in roots of carrot at $10 \%$ of FMC. Moreover, the increase in $\mathrm{Cd}$ in shoots and roots of sugar beet was $26.31 \%$ and $21.00 \%$, respectively higher than control at 50\% FMC concentration (Figs. 5 and 6). In carrot control, Cd content in shoots $(0.098 \mu \mathrm{g} / \mathrm{g} \mathrm{DW})$ was lesser than in roots $(0.146 \mu \mathrm{g} / \mathrm{g} \mathrm{DW})$. On the other hand the Cd content in both controls shoots and roots of sugar beet was almost equal.

Relationship between heavy metals in plant and soil

Correlation analysis was carried out between the concentrations of heavy metals in shoots \& roots of carrot \& sugar beet plants and the absolute contents in the soils; (calculated by using the data of their concentrations in the sand and FMC levels) (Tables 3 and 4). In carrot plants, there are a high significant positive correlation between $\mathrm{Zn}$ of soil with $\mathrm{Zn}$ of both roots and shoots; also $\mathrm{Cd}$ had significant correlation with $\mathrm{Cd}$ roots. However, there are a positive correlation between cu soil with $\mathrm{Cu}$ roots and shoots, $\mathrm{Cd}$ soil with $\mathrm{Cd}$ shoot and $\mathrm{Pb}$ soil with $\mathrm{Pb}$ roots. Conversely, the correlation between $\mathrm{Pb}$ soil and $\mathrm{Pb}$ shoots was negative. In sugar beet plants, there are a high significant positive correlation with both $\mathrm{Zn}$ and $\mathrm{Cu}$ soil with $\mathrm{Zn}$ and $\mathrm{Cu}$ shoots and roots. $\mathrm{Pb}$ showed positive correlation with shoots $\mathrm{Pb}$ and roots $\mathrm{Pb}$. Cd of soil had negative highly significant with $\mathrm{Cd}$ shoots and roots . 
TABLE 3. r-values of correlation analysis between concentrations of heavy metals in shoots and roots of carrot plants and absolute quantities in the soil.

\begin{tabular}{lcccccccc}
\hline & \multicolumn{7}{c}{ Carrot } \\
\hline Pb shoot & Zn shoot & Cu shoot & Cd shoot & Pb root & Zn root & Cu root & Cd root \\
\hline Pb soil & -0.253 & $0.683^{*}$ & -0.124 & -0.226 & 0.069 & 0.422 & 0.250 & -0.395 \\
Zn soil & 0.565 & $0.965^{* *}$ & 0.551 & -0.311 & $0.729^{* *}$ & $0.895^{* *}$ & 0.489 & $-0.909^{* *}$ \\
$\mathrm{Cu}$ soil & 0.496 & $0.953^{* *}$ & 0.296 & -0.255 & 0.526 & $0.921^{* *}$ & 0.220 & $-0.755^{* *}$ \\
$\mathrm{Cd}$ soil & 0.047 & $-0.812^{* *}$ & -0.155 & 0.302 & -0.324 & -0.546 & -0.433 & $0.610^{*}$ \\
\hline
\end{tabular}

The significant $\mathrm{r}$-values are marked by stars, ${ }^{*}: \mathrm{P}<0.05$ and ${ }^{* *}: \mathrm{P}<0.01$.

TABLE 4. r-values of correlation analysis between concentrations of heavy metals in shoots and roots of sugar beet plants and absolute quantities in the soil.

\begin{tabular}{lcccccccc}
\hline \multicolumn{7}{c}{ Sugar beet } \\
\hline Pb soil & 0.572 & 0.530 & $0.670^{*}$ & 0.554 & 0.292 & $0.700^{*}$ & $0.642^{*}$ & 0.537 \\
Zn soil & $0.953^{* *}$ & $0.974^{* *}$ & $0.975^{* *}$ & $0.973^{* *}$ & $0.863^{* *}$ & $0.954^{* *}$ & $0.981^{* *}$ & $0.871^{* *}$ \\
Cu soil & $0.882^{* *}$ & $0.882^{* *}$ & $0.979^{* *}$ & $0.916^{* *}$ & $0.886^{* *}$ & $0.891^{* *}$ & $0.936^{* *}$ & $0.759^{* *}$ \\
Cd soil & $-0.756^{* *}$ & $-0.715^{* *}$ & $-0.795^{* *}$ & $-0.736^{* *}$ & -0.436 & $-0.839^{* *}$ & $-0.792^{* *}$ & $-0.774^{* *}$ \\
\hline The significant r-values are marked by stars, ${ }^{*} \mathrm{P}<0.05$ and ${ }^{* *}: \mathrm{P}<0.01$. & & & & &
\end{tabular}

\section{Discussion}

Organic materials promote the metabolic activity inside the plant and enhance the movement of the metabolites through the roots toward the leaves; so the nutrient content of the plants may increase (Sikander, 2001). In the present study, the Filter mud cake significantly improved mineral content and heavy metals in carrot and sugar beet plants and it effect on distribution of mineral and heavy metals in roots and shoots. Our results showed that in general, there was a significant increase in $\mathrm{K}, \mathrm{Ca}, \mathrm{Mg}, \mathrm{Cl}, \mathrm{PO}_{4}$ and $\mathrm{SO}_{4}$ contents in carrot and sugar beet plants under FMC treatments compared to control. This increase in mineral may be due to enhanced microbial activates, which increase nutrient availability and their uptake and increasing root distribution. (Yassen et al., 2010). As well as this increase may be attributable to promotion of root growth by filter mud cake and hence increase the capacity to absorb nutrients (Abo-Baker \& El-Tayeh, 2017). Kabesh et al. (2009) and Abo-Baker (2017) who reported that organic fertilizers amended with biofertilizers caused significant increases in the $P$ and $\mathrm{K}$ uptake in wheat plants. Moreover, Hadad et al. (2015) reported that the increase in $\mathrm{P}$ and $\mathrm{K}$ in corn and wheat plants may be attributed to the high content of these nutrients in Filter mud cake. Our results showed significant decrease in $\mathrm{Na}$ content in shoots of carrot and sugar beet. The higher $\mathrm{Na}$ levels in roots as compared to shoots in all treatment may be due to plant restricted transport of $\mathrm{Na}$ to upper shoots to minimize its detrimental effects (Ramoliya et al., 2004). The distribution of $\mathrm{Na}$ and $\mathrm{K}$ was in a reverse way, and mostly $\mathrm{Na}$ accumulated in roots while more $\mathrm{K}$ transported into shoots of the plants. This may be due to the fact that $\mathrm{K}$ is needed for the newly developed and photosyntheticaly active tissues (Abu Zuhri, 2004). Results of the present investigation indicated that $\mathrm{Na} / \mathrm{K}$ ratio was higher in plant roots than shoots. The low $\mathrm{Na} / \mathrm{K}$ molar ratios in shoots of the plants because $\mathrm{K}$ is required by the various enzymatic processes in the cytoplasm, so less Na can compete with $\mathrm{K}$ for binding sites essential for cellular function and did not substitute it (Bhandal \& Malik, 1988). So, disruption of various enzymatic processes did not take place. Also, because high concentrations of $\mathrm{K}$ is needed for protein synthesis (Blaha et al., 2000). It is well established that potassium is generally the most prevalent ion in plant tissue and that $\mathrm{K}$ has important role in maintaining the osmotic potential and activate certain enzymes; whereas the concentration of $\mathrm{Na}$ is very low and this ion has no obvious metabolic role in most plants. Data indicated that carrot and beet plants retained $\mathrm{Na}$ in their roots and tend to transport more $\mathrm{K}$ into their shoots. However, most of higher plants have developed high selectivity in the uptake of $\mathrm{K}$ as compared with that of $\mathrm{Na}$. 
PM application induced increase in S uptake by mustard and $\mathrm{Ca}$ uptake by wheat and maize (Solaimala et al., 2001). Since, Sulfur is a vital component of proteins through the amino acids cysteine and methionine and an active constituent of numerous coenzymes and prosthetic groups, iron sulfur centres, coenzyme-A, thiamine, lipoic acid, S-adenosylmethionine, glutathione, and many more (Kopriva et al., 2015). While calcium participates in formation of cell wall and plasma membrane, cell growth and secretion and hormonal or modulating physiological processes and serves as secondary messenger in cell (Lo'pez-Lefebre et al., 2001). Heavy metals present in soils can easily accumulate in plant tissues. Plant species differ in their uptake and distribution of heavy metals in their organs and in their effect on rhizosphere and bulk soil metal concentration. Soil properties, such as $\mathrm{pH}$, organic matter content and presence of other elements affect plant uptake, solubility and mobility of these elements (Salama \& El-Tayeh, 2012). The application of FMC as a source of organic matter resulted in a higher increase in $\mathrm{Zn}, \mathrm{Cu}, \mathrm{Cd}$ and $\mathrm{Pb}$ content in the investigated plants. The increased solubility of these metals in the soil amended with FMC could be due to the decrease in soil pH (Brallier et al., 1996). The addition of organic material to the soil increased the percentages of available $\mathrm{Zn}, \mathrm{Cu}$ and $\mathrm{Pb}$ (Abo-Baker \& ElTayeh, 2017). Usman et al. (2004) found that the mobility of heavy metals can be increased by the addition of sewage sludge. Also Temminghoff et al. (1998) reported that the mobility of heavy metals increased with soluble organics. Ayari et al. (2010) reported that as for compost-amended soils, heavy metals in plants were significantly greater than in control. The higher contents of $\mathrm{Pb}, \mathrm{Cu}, \mathrm{Cd}$ and $\mathrm{Zn}$ in investigated plants treated with FMC might be due to the occurrence of additional heavy metals in treatment of the FMC, which added extra metals in the soil environment (Kumar \& Chopra, 2016). The buildup of the Zn, $\mathrm{Cu}, \mathrm{Cd}$ and $\mathrm{Pb}$ in the carrot and sugar beet plants (except $\mathrm{Zn}$ shoots of carrot) was noted below the permissible limit of the FAO/WHO standards for the $\mathrm{Cd}\left(0.20 \mathrm{mg} \mathrm{Kg}^{-1}\right), \mathrm{Pb}\left(5.0 \mathrm{mg} \mathrm{Kg}^{-1}\right), \mathrm{Cu}$ (40.00mg Kg $\mathrm{Kg}^{-1}$ ) and $\mathrm{Zn}$ (60.00mg Kg $\mathrm{Kg}^{-1}$ (FAO/ WHO, 2007). The bioavailability of measured heavy metals in carrot and sugar beet plants might be increased due to the ionization in the aqueous phase in the soil which increases their reactivity and instability as earlier reported by Kumar \& Chopra (2014). Nunome et al. (2001) reported the contamination of $\mathrm{Cd}, \mathrm{Cu}, \mathrm{Cr}, \mathrm{Zn}$ and $\mathrm{Pb}$ in soil and Solanum melongena subsequent to application of sugarcane pressmud and effluent.

The present results showed that in general heavy metal accumulation was more in shoots than roots under FMC amendment. Salama \& ElTayeh (2012) reported that Ni transported up to the shoots of cotton plants, while low amounts were detected in roots. The accumulation of heavy metals in carrots and sugar beet plants grown on sandy soil amended with FMC was generally arranged in the following preference: $\mathrm{Zn}>\mathrm{Cu}>$ $\mathrm{Pb}>\mathrm{Cd}$.

Correlation analysis between the contents of heavy metals in both organs of carrot and sugar beet plants and that in the sand-FMC mixture showed different relationships, for examples, $\mathrm{Zn}$ concentration in shoots of sugar beet $(\mathrm{r}=$ $0.974)$ and roots $(r=0.954)$ had a highly positive correlation with that in FMC. While, in case $\mathrm{Cd}$ of carrot there was correlation between $\mathrm{Cd}$ concentration in shoots $(\mathrm{r}=0.302)$ and in roots $(\mathrm{r}=$ 0.610 ) of plants and that of FMC, this revealed that $\mathrm{Cd}$ accumulated in shoots less than in roots. Moreover, in case $\mathrm{Pb}$ in sugar beet there was correlation between $\mathrm{Pb}$ concentration in shoots $(0.572)$ and in roots $(0.292)$ of plants and that of FMC, this indicated that $\mathrm{Pb}$ accumulated in shoots more than in roots.

\section{Conclusion}

It can be concluded that at addition of filter mud cake (FMC) to sand soil, carrot and sugar beet plants accumulate higher contents of mineral $(\mathrm{K}$, $\mathrm{Ca}, \mathrm{S}$ and $\mathrm{P}$ ) especially in roots. Moreover, roots of investigated plants had less amounts of heavy metal than shoots. So, addition of FMC increased value of yield of carrot and sugar beet plants.

\section{$\underline{\text { References }}$}

Abo-Baker, A.A. (2017) Successive application impact of some organic amendments combined with acid producing bacteria on soil properties, NPK availability and uptake by some plants. International Journal of Current Microbiology and Applied Sciences, 6(3), 2394-2413.

Abo-Baker, A.A. and El-Tayeh, N.A. (2017) Heavy metal and phosphorus contents of Jew's mallow (Corchorus olitorius L.) plants grown on soil 
amended with phosphate, bio and organic fertilizers. International Journal of Plant \& Soil Science, 14(6), 1-19.

Abu Zuhri, K.M.B. (2004) The environmental impact of sewage sludge application on growth and heavy metals uptake and translocation in sunflower and sorghum plants. Ph.D. Thesis, Faculty of Science, Assuit University, Egypt.

Allen, S.E. (1989) "Chemical Analysis of Ecological Materials" $\left(2^{\text {nd }} \quad\right.$ ed. $)$ Blackwell Scientific Publications, Oxford. 368p.

Ayari, F., Hamdi, H., Jedidi, N., Gharbi, N. and Kossai, R. (2010) Heavy metal distribution in soil and wheat plants in municipal solid waste compost-amended plots. International Journal of Environmental Science Technology, 7(3), 465-472.

Bardsley, C.E. and Lancaster, J.D. (1965) Sulfur. In: "Methods of Soil Analysis", Part 2. Black, C.A., Evans, D.D., White, J.L., Jnsminger, L.E., Clark, F.E. (Ed.), pp. 1102-1116. Agronomy. Series No. 9. Madison, Wisconsin: American Society of Agronomy, Inc.

Bhandal, I.S. and Malik, C.P. (1988) Potassium estimation, uptake, and its role in the physiology and metabolism of flowering plants. International Review of Cytology, 110, 205-254.

Blaha, G., Stelzl, U., Spahn, C.M.T., Agrawal, R.K., Frank, J. and Nierhaus, K.H. (2000) Preparation of functional ribosomal complexes and effect of buffer conditions on tRNA positions observed by cryoelectron microscopy. Methods in Enzymology, 317, 292-309.

Brallier, S., Harrison, R.B., Henry, C.L. and Dongsen, X. (1996) Liming effects on availability of $\mathrm{Cd}, \mathrm{Cu}$, $\mathrm{Ni}$, and $\mathrm{Zn}$ in a soil amended with sewage sludge 16 years previously', Water Air Soil Pollution, 86, 195-206.

Chauhan, R.P.S. (1995) Effect of amendments on sodic soil reclamation and yield and nutrients uptake of rice (Oryza sativa) under rice-fallow-rice system. Indian Journal of Agricultural Sciences, 5(6), 438-441.

FAO/WHO (2007) Joint WHO (World Health Organization)/FAO (Food and Agriculture Organization), Food standard programme codex alimentarius commission, $13^{\text {th }}$ Session, Report of the thirty eight session of the codex committee on food hygiene, ALINORM 07/ 30/13, FAO/WHO, Houston, USA 2007.

Hadad, H.M. (2015) Studies on organic decomposition and release of nutrients and heavy metals in soils amended with some organic wastes. Ph.D. Thesis, Faculty of Agric., Assiut Univ., Assiut, Egypt.

Hassan, M.M. (1999) Organic refuses composted by micro-organisms and their effect on the availability of some nutrients in newly reclaimed soils. Ph.D. Thesis, Fac. Agric., Zagazig Univ., Egypt.

Hoagland, D.R and Arnon, D.I. (1950) "The Water Culture Method for Growing Plants without Soil". California Agricultural Experimental Station, Cir: pp. 347-352.

Johnson, C.M. and Ultrich, A. (1959) Analytical Methods for Use in Plant Analysis. United States Department Agriculture California University of Agriculture information Bull. 766.

Kabesh, M.O., El-kramany, M.F., Sary, G.A., El-Naggar, H.M. and Bakhoum, G.S.H. (2009) Effect of sowing methods and some bio-organic fertilization treatments on yield and yield components of wheat. Research Journal of Agriculture and Biological Science, 5(1), 97-102.

Kopriva, S., Calderwood, A., Weckopp, S.C. and Koprivova, A. (2015) Plant sulfur and Big Data. Plant Science, 241, 1-10.

Kumar, V. and Chopra, A.K. (2014) Ferti-irrigational response of hybrid cultivar of Indian mustard (Brassica juncea L.) to distillery effluent in two seasons. Analytical Chemistry Letters, 4(3), 190206.

Kumar, V. and Chopra, A.K. (2016) Effects of sugarcane pressmud on agronomical characteristics of hybrid cultivar of eggplant (Solanum melongena L.) under field Conditions. International Journal of Recycling of Organic Waste in Agriculture, 5, 149-162.

Lo'pez-Lefebre, L.R., R.M. Rivero, R.M., Garc1'a, P.C., Sa'nchez, E., Ruiz, J.M. and Romero, L. (2001) Effect of calcium on mineral nutrient uptake and growth of tobacco. Journal of the Science of Food and Agriculture, 81,1334-1338. 
Muhammad, D. and Khattak, R.A. (2009) Growth and nutrient concentrations of maize in pressmud treated saline-sodic soils. Soil \& Environmental 28(2), 145-155.

Nunome, T., Ishiguro, K., Yoshida, T. and Hirai, M. (2001) Mapping of fruit shape and color development traits in eggplant (Solanum melongena L.) based on RAPD and AFLP markers. Breed Science, 51, 19-26.

Prado, R.M, Caione, G. and Campos, C.N.S. (2013) Filter cake and vinasse as fertilizers contributing to conservationagriculture.AppliedandEnvironmental Soil Science, 2013, Article ID 581984, 8 pages http://dx.doi.org/10.1155/2013/581984

Ramoliya, P.J., Patel, H.M. and Pandey, A.N. (2004) Effect of salinisation of soil on growth and macroand micro-nutrient accumulation in seedlings of Acacia catechu (Mimosaceae). Annals of Applied Biology, 144, 321-332.

Razzaq, A. (2001) Assessing sugarcane filter cake as crop nutrients and soil health ameliorant. Pakistan Sugar Journal, 21(3), 15-18.

Richards, L.A. (Ed.) (1954) "Diagnosis and Improvement of Saline and Alkali Soils". US Department. Agriculture. Handbook.

Rizk, M.H. (2012) Effect of some legume cover crops and organic fertilizer on petiole nutrient content, productivity and fruit composition of 'Thompson seedless' grapevines. Acta Horticulturae, 933, 381-387.

Salama, F.M. and El-Tayeh, N.A. (2012) Accumulation and distribution of minerals and heavy metals in cotton plants grown on soil amended with urban sewage sludge. Egyptian Journal of Botany, 52, 159-176.

Schwarzenbach, G. and Biedermann, W. (1948) Komplexonex. Erdalkalikomplexe van, o,6Doxyazofarbstoffen Helv. Chemical Acta, 31, 678-687.

Sharma, K.D., Karki S., Thakur, N.S. and Attri, S. (2012) Chemical composition, functional properties and processing of carrot. Journal of Food Science and Technology, 49, 22-32.

Sikander, A. (2001) Effect of organic manure and inorganic fertilizers on the dynamics of soil microorganism: biomass, composition and activity. In: "Alternate/organic fertilizers" D8 Workshop, Islamabad, Pakistan. 19-20 June; 2001.

Solaimalai, A., Baskar, M., Rarnesh, P.T. and Ravisankar, N. (2001) Utilisation of press mud as soil amendment and organic manure: A review. Agriculture Reviews, 22(1), 25-32.

Taha, M.B. (2000) Effect of using some organic amendments for improving the productivity of coarse textured soils. M.Sc. Thesis, Fac. Agric., AlMinia Univ., Egypt.

Temminghoff, E.J.M., van der Zee, S.E.A.T.M. and De Haan, F.A.M. (1998) Effects of dissolved organic matter on the mobility of copper in a contaminated sandy soil. European Journal of Soil Science, 49, 617-628.

Usman, A.R.A., Kuzyakov, Y. and Stahr, K. (2004) Dynamic of organic $\mathrm{C}$ mineralization and the mobile fraction of heavy metals in a calcareous soil incubated with organic wastes. Water, Air and Soil Pollution, 158, 401-418.

Vogler, P. (1965) Probleme der phosphatanalytik in der limnologie und ein neues verfahren zur bestimmung von gelostem orthophosphate neben kondensierten phosphaten und organischen phosphorus-estern. International Revue der Gesamten Hydrobiologie, 50, 33-48.

Williams, C.H and Twine, M.E. (1960) Flame photometric method for sodium, potassium and calcium. In: "Modern Methods of Plant Analysis", Paech, K. and Tracey, M.V. (Eds.), Vol. 5, 535p. Springer-Verlag, Berlin.

www.trafoon.org/sites/trafoon.orgfiles/download/1196/ olsztyn_lech_michalczuk_20160912.pdf.

Yassen, A.A, Khaled, S.M. and Zaghloul, S.M. (2010) Response of wheat to different rates and ratios of organic residues on yield and chemical composition under two types of soil. Journal of American Science, 6(12), 858-864.

(Received 15/8/2018; accepted $11 / 10 / 2018$ ) 


\section{تراكم وتوزيع المعادن الغذائية و الثقيلة في نباتات الجزر و البنجر النامية على تربة مسمدة بحمأة مصانع قصب السكر أمعادن التعر \\ فوزي محمود سلامة(1)، نهي أحمد التاية(2)، نجلاء لطفي(2)، منى فوزي أبوالحمد (2)

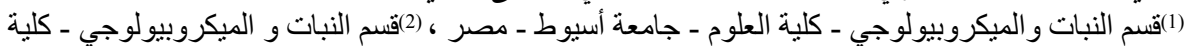

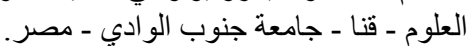

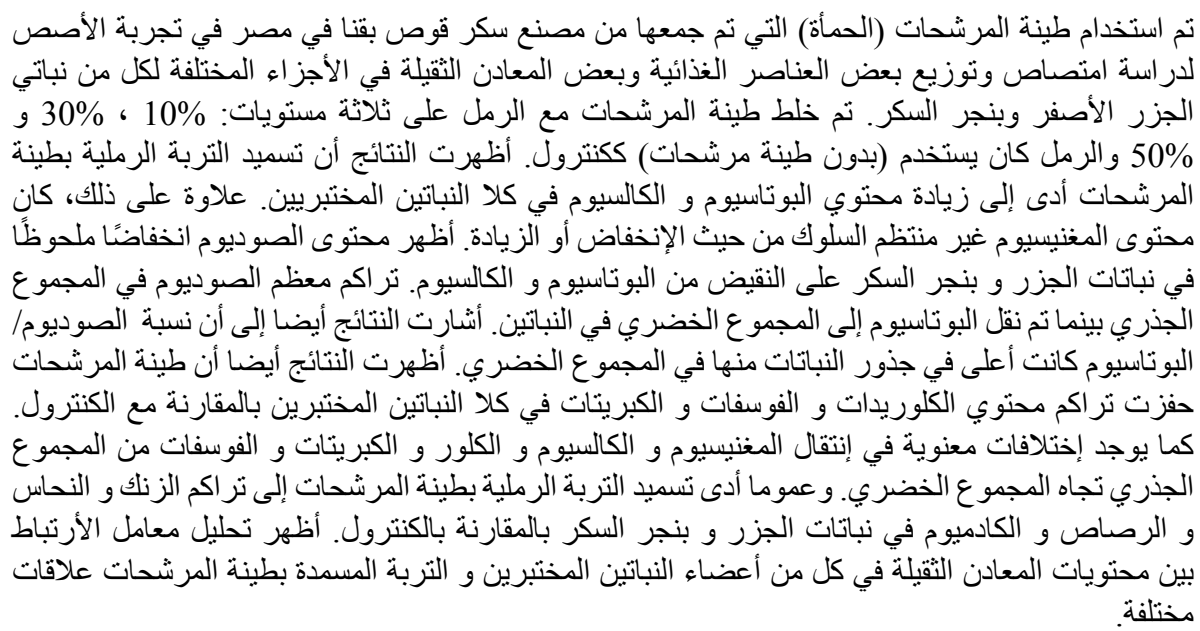

